\title{
WILLIAMSON MODEL: AN APPLICATION OF INSTITUTIONAL TRANSFORMATION IN THE INDONESIAN DGT
}

\author{
Wihana Kirana Jaya, Anggi Rahajeng, \& Indra Bastian \\ Faculty of Economics and Business \\ Universitas Gadjah Mada \\ (wihanajaya@feb.ugm.ac.id)
}

\begin{abstract}
A reform of tax administration in Indonesia has been carried out in several stages from 1983 to 2009. However, the changes are limited to the tax system of the DGT, it being the tax governing body in Indonesia, which has still has not managed to meet the tax revenue target (reflected through a tax ratio). A lack of authority caused the DGT (DGT) to face some difficulties in reaching the target and demonstrating the expected performance. The goal of this paper is to stress the needs of institutional transformation in DGT. By using the Williamson Model, this study focuses on evaluating the DGT institutionally and creating an alternative institutional transformation of the DGT. The international and domestic results of ascertaining best practices conclude that the DGT needs to change gradually, not with a 'big bang', and by providing the more flexible authority by remaining in the structure of Traditional Department or Single Directorate in the Ministry of Finance (SDMOF) which would lead to an organization structure which is semi-autonomous or a Unified Semi-autonomous Body (USB) that covers all the systems of taxation such as service, assurance, law enforcement and supporting roles.
\end{abstract}

Keywords: tax governing body, Indonesian DGT (DGT), institutional transformation, williamson model

\section{INTRODUCTION}

Taxation Indonesian politics is closely related to the National Budget (APBN). According to data from the Fiscal Policy Office (December, 2014) the value of the national budget increased significantly from early 2004, which only amounted to IDR 427.2 trillion, to IDR 1,639.4 trillion in 2013 which means that there has been an almost four-fold rise in the last decade. Indeed, in the 2014, the revised national budget draft document expenditure increased to IDR 1,849.5 trillion which means total government expenditure accounted for between $16.2 \%$ and $19.9 \%$ of the total Gross Domestic Product (GDP) of Indonesia.

National expenditures funded from revenue, as we $^{1}$ see them originate from the contribution

\footnotetext{
${ }^{1}$ It is acknowledged that this paper was modified from a research report written by Wihana Kirana Jaya, Anggi Rahajeng and Indra Bastian with the title "Kajian
}

of natural resources, the mining sector for example, and the results of SOEs, are still relatively small and international resources undeniably could bring some other problems. Inevitably Indonesia is relatively dependent on tax revenues. When viewed from the ratio of tax revenues to GDP (tax ratio) reached approximately $12 \%$. In general trend Indonesian tax ratio is also relatively low compared to other countries of the Organization for Economic Co-operation and Development (OECD), non-OECD, emerging markets even in other ASEAN countries, namely $13.3 \%$, while the OECD countries by $34 \%$ and non-OECD at 26.8\% (OECD, 2013). This figure is relatively stagnant for ten years so as to estimate the ratio of Indonesian tax until 2018 also remains relatively low at about $12.12 \%$ with a relatively high ratio gap of about $7.43 \%$.

Kelembagaan Direktorat Jenderal Pajak, 2015” on which collaborated with AIPEQ and the Indonesian Directorate General of Taxes 
Tax administration reform in Indonesia has been carried out in several stages from 1983 to 2009. However, the changes are limited to the tax system of the DGT, it being the tax governing body in Indonesia, which has still has not managed to meet the tax revenue target (reflected through a tax ratio), to improve each taxpayer's compliance, and to achieve good governance practice.

The lack of authority caused the DGT to face some difficulties in reaching the target and demonstrating the expected performance. As the governing tax body in the form of a single directorate in the Ministry of Finance(MOF), the obstacles that existed were in the form of the regulation and governance policies of government organizations and civil service regulation in Indonesia. These conditions became a cause of the limited space for the DGT, especially in meeting the challenges and demands of today's society.

In this case, an institutional transformation should be investigated as a discourse. The dis- course emerged as an alternative space for the tax management without having been bound rigidly by any government regulation. However, a preliminary institutional study on the DGT institutionally should be examined in terms of the need for institutional transformation, and effective institutional form in Indonesia.

\section{THEORETICAL FRAMEWORKS: WILLIAMSON MODEL}

An institutional economics approach is utilized as a theoretical framework. Institutional economics is defined as the rules of the informal and formal regulations affecting governance and the form the incentive structure (Wihana, 2010). The level analysis explored in this institutional study of the DGT can be detailed as:

1. Regulation: legal and regulatory foundation.

2. Business process: governance framework.

3. Organization: resource allocation.

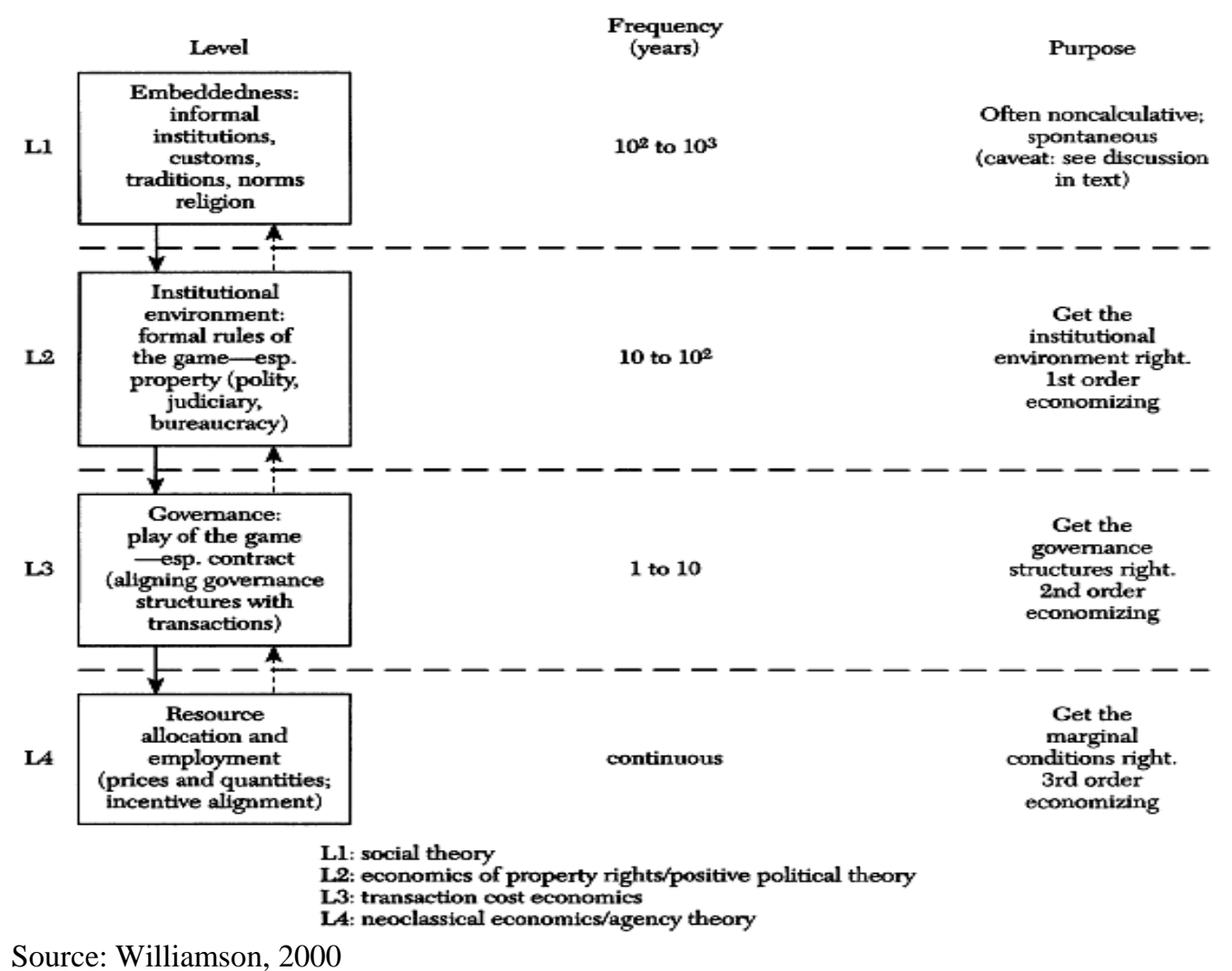

Figure 1. Four Levels of Social Analysis, Williamson 
In this study, data triangulation has been collected as material for analysis:

1. Focus Group Discussions (FGD) which were held on:

a. October 2, 2014 in Solo with staff from the Indonesian DGT

b. October 8, 2014 in Jakarta with staff from the Indonesian DGT, INTRAC (PPATK), State Audit Agency (BPK), the Police, Judiciary, and Corruption Eradication Commission (KPK), Special Task Force Implementation of Upstream Oil and Gas (Satuan Kerja Khusus Pelaksana Kegiatan Usaha Hulu Minyak dan Gas Bumi/SKK Migas), Deposit Insurance Corporation (Lembaga Penjamin Simpanan/LPS)

c. October 15, 2014 in Jakarta with participants including Tax Consultants, INTRAC (PPATK), Corruption Eradication Commission (KPK), Bank Indonesia (Central Bank), Ministry of Finance

d. October 16, 2014 in Jakarta with participants including academics, business association (APINDO), PBNU, Ernst \&Young, Australian Treasury, ADB, World Bank, IMF, AIPEG, LAN

2. Literature Study.

3. In-depth Interview with staff from the Indonesian DGT

\section{EVALUATION ON THE EXISTING CONDITION OF THE DGT}

The first objective of the study is to evaluate the current condition of the DGT (DGT) as the tax management body in Indonesia. The performance of the DGT in terms of the resulting state revenues over the last ten years shows that it is still very buoyant, less elastic, with stagnant yields, and stable in terms of the increase of GDP. Now, the performance of DGT can be seen in the low of tax ratio, the taxpayers' formal compliance level in Indonesia, which is also still low with a compliance rate of $60.8 \%$ as opposed to the target of $65 \%$ in 2013 , the low rate of audit coverage which was only $0.25 \%$ in 2013. These conditions are also exacerbated by an imbalance in the ratio of the number of inspectors and Account Representatives (AR) to taxpayers i.e. 1:2,558 in 2013 (DJP, 2014). It concluded that the performance of the DGT has has not been optimal. The lack of authority possessed by the DGT is believed to be the main cause of its low effectiveness and efficiency. As a governing tax body, the Directorate only has some limited authority with regard to the tax system. It has no authority to regulate its own organization, human resources, and its own budget. The DGT needs authority if it is to improve the quality of governance and the integrity of tax administration.

By looking at the current condition of the DGT, which is not working optimally, caused by its lack of authority, a restructuring of its governance and institutional transformation is urgently needed.

The institutional transformation, according to international benchmarking for best practices in the transformation of public institutions, the DGT is set at least one for each of the following categories:

1. SDMOF: Single Directorate in the Ministry of Finance.

2. MDMOF: Multiple Directorates in the Ministry of Finance.

3. USB: Unified Semi-autonomous Body.

4. USBB: Unified Semi-autonomous Body with Board.

Indonesia has adopted a self-assessment tax under Law No.28 2007 on General Provisions and Tax Procedures by the Directorate General of Taxes as the agency designated to administer tax under the Ministry of Finance. The DGT manages central government taxes: Value Added Tax (VAT) based on Law 42/2009, the Income Tax based on Law 36/2008 and the Land and Building Tax especially for plantations, forestry and mining (Law 2/1994 and Law20/2000). According to Presidential Decree 24/2010, the DGT duties are to formulate and implement taxation policies, to establish norms, standards, procedures, criteria (NSPK), to provide technical guidance and evaluation in the field of taxation, and the administration of the DGT. 
In performing these duties, the DGT has the following functions:

1. Policy formulation in the field of taxation.

2. Implementation of policies in the field of taxation.

3. Preparation of norms, standards, procedures, and criteria in the field of taxation.

4. Providing technical guidance and evaluation in the field of taxation.

5. Implement the administration of the DGT.

Broadly speaking, the main function of the DGT is the tax administration, including management and has major business processes in the field of tax services to the taxpayer and tax monitoring and enforcement so, by the institutional nature of the organization, the DGT has specific duties that are rigid and unique compared to other public organizations.

Based on the duties and functions of the DGT, it is expected to be a tool for the state (the executive, legislative and judicial branches) to collect revenue from the public through taxation to finance the administration of the state. By way of evaluation, has the DGT already performed its basic tasks and functions optimally? It can be seen from some of the following issues:

1. The contribution of tax revenues in the state budget, in 2014 approximately $60 \%$ to $70 \%$ has not been reached. A short fall occured on state income tax (Bisnis Indonesia, October 2014).

2. A potential utilization. The population of Indonesia is currently about 253 million people and according to data from the Central Bureau of Statistics (Badan Pusat Statistik/BPS) those with the potential to pay taxes (taxpayers) number approximately 110 million people while the taxpayer data held by the DGT is about 26 million. This means there are 84million potential taxpayers who have not been optimized (Kismantoro, 2014).

If the DGT is to perform its functions optimally, it needs to be supported by several aspects such as human resources, budget and organizational structure.

\section{INSTITUTIONAL ANALYSIS OF THE DGT WITH BEST PRACTICES}

The institutional evaluation of the Directorate General of Taxes is conducted using two approaches. First, by comparing the best practice with tax authority institutions/the state revenue in selected foreign countries and, second, the comparing best practice with the selected governmental institutions in Indonesia such as Bank Indonesia (Central Bank), KPK (Corruption Eradication Commission), PPATK (Indonesian Financial Transaction Reports and Analysis Center/INTRAC), Financial Services Authority (Otoritas Jasa Keuangan/OJK), Special Task Force for the Implementation of Upstream Oil and Gas (Satuan Kerja Khusus Pelaksana Kegiatan Usaha Hulu Minyak dan Gas Bumi/SKK Migas), Deposit Insurance Corporation (Lembaga Penjamin Simpanan/LPS) etc. as domestic best practices.

There is a lot of literature which discusses the institutional form of tax authorities that are semi-autonomous revenue authorities (SARAs) in various countries such as New Zealand, Singapore and others in Africa and Latin America (Taliercio, 2003). The application of SARAs is not the only rapid and appropriate way for developing countries. The tax ratio and low income, corruption, less efficient administration, that are seen in the Ministry of Finance, along with tax evasion, do not automatically and immediately become the reason why such countries form a tax authority institution by applying SARAs. It is true but in some conditions, not all of these require this way of forming an institution. If SARAs is formed, then it needs to prepare infrastructure/facilities which can anticipate institutional changes, and successful performance in the long-term that depends on the power and quality of SARAs leadership, political will and ongoing support from government and the private sector (Mann, 2004).

A state revenue agency (Revenue Authority -RA) outside the Ministry of Finance is a solution to overcome the problems of low performance regarding collection of state revenue, the level of compliance, ineffective staff and corruption, so that it will be more accountable (Crandal 
\& Kidd, 2006). The semi-autonomous agency outside the Ministry of Finance also has the authority to manage the finance independently (Taliercio, 2003). Thus, with this authority, the agency would be able to provide both incentives and disincentives in collecting the tax (Haldenwang, et.al., 2013). Administrative autonomy of a state revenue authority is reflected in these four items: the provisions stated in the regulations of the state revenue authority, the reporting relations, the ability to design and implement the operational policy, and organizational structure and its operational responsibilities.
Acording to the surveys carried out by OECD on the state revenue agencies in OECD member countries and non-OECD countries, unlike those whose tax authority is under the Ministry of Finance (single directorate) such as France, Netherlands, and Switzerland, the DGT in Indonesia does not have any authority to design its internal structure. The DGT also does not have any authority in budgeting so it is less flexible in the face of the change related to program development and cannot make any adjustments to deal with the Indonesian tax situation which is relatively dynamic.

Table 1. The Authority of the Tax Authorities in Indonesia and Selected Countries

\begin{tabular}{|c|c|c|c|c|c|c|c|c|c|}
\hline \multicolumn{10}{|c|}{ Single Directorate in Ministry of Finance } \\
\hline French & v & v & $v$ & v & $v$ & $v$ & $v$ & $v$ & $v$ \\
\hline Indonesia & 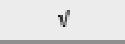 & v & $x$ & $x$ & $v$ & $v$ & $v^{\prime}$ & $x$ & $x$ \\
\hline Swiss & $\checkmark$ & $\checkmark$ & $\sqrt{ }$ & v & $\sqrt{ }$ & $\sqrt{ }$ & $\checkmark$ & $\sqrt{ }$ & $\sqrt{ }$ \\
\hline \multicolumn{10}{|c|}{ Multiple Directorates in Ministry of Finance } \\
\hline Belgium & $\sqrt{ }$ & $\sqrt{ }$ & $\mathrm{x}$ & $x$ & $v$ & $\mathrm{x}$ & v & $x$ & $\mathrm{x}$ \\
\hline Australia & $\sqrt{ }$ & v & $v$ & v & $v$ & $v$ & v & V & $v$ \\
\hline Brazil & $\checkmark$ & v & $x$ & $x$ & $x$ & $x$ & $\checkmark$ & $x$ & $x$ \\
\hline India & $\sqrt{ }$ & v & $v$ & v & $v$ & $v$ & $\checkmark$ & $\sqrt{ }$ & $x$ \\
\hline Japan & $\sqrt{ }$ & v & $x$ & $y$ & $v$ & $x$ & v & $\sqrt{ }$ & $x$ \\
\hline $\begin{array}{l}\text { Czech } \\
\text { Republic }\end{array}$ & v & V & $v$ & v & $v$ & $v$ & $v$ & $\sqrt{ }$ & $\checkmark$ \\
\hline \multicolumn{10}{|c|}{ Unified Semi-Autonomous Body with Board } \\
\hline South Africa & 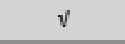 & v & $v$ & v & $v$ & $v$ & v & $\sqrt{ }$ & $v$ \\
\hline \multicolumn{10}{|c|}{ Other } \\
\hline Malaysia & $\sqrt{ }$ & $\checkmark$ & $\sqrt{ }$ & $\sqrt{ }$ & $\sqrt{ }$ & $x$ & $\checkmark$ & $\sqrt{ }$ & $\sqrt{ }$ \\
\hline China & $\sqrt{ }$ & $\sqrt{ }$ & $\sqrt{ }$ & $\sqrt{ }$ & $\sqrt{ }$ & $\sqrt{ }$ & $\sqrt{ }$ & $\sqrt{ }$ & $x$ \\
\hline
\end{tabular}

Source: OECD Tax Administration, 2013

OECD

Non-OECD 
In terms of human resource management, the DGT does not have any authority including hiring or dismissing of employees, and arranging its employees' salaries, so it is difficult to arrange both incentives and non incentives, and carrying out renumeration, since all are centralized in the Ministry of Finance and bound by regulations pertaining to civil servants. Meanwhile, it shows that some countries with a semiautonomous system (with or without board) tend to have the high degree of autonomy.

In general, the performance of the authority of tax revenues increased after becoming a semiautonomous body, although the experience of various countries also shows that the formation of a semi-autonomous body is not necessarily a "panacea" for improving/optimizing revenue.

Mann (2004) asserted that the establishment of the semi-autonomy of the state revenue agency (SARA) is not a "panacea" to improve collection and reduce the problem of inefficiency in tax administration, as SARA only provides a platform so that positive reform can occur, but SARA can also be a catalyst and facilitate reform, but the formation of SARA is only necessary and not sufficient in and of itself to lead to reform.

This means that the legal and institutional reforms that create SARA are not complete unless they accompanied by reforms to the whole process and all procedures throughout the entire tax collecting agency. Inefficiencies can continue to run without a total overhaul of the internal processes and procedures, and strengthening of the regulatory framework and accountability that connects SARA with other public sector institutions and the private sector (taxpayers). Internal conflict or friction can occur between the Ministry of Finance (and ministers) and SARA and/or between the board and the director of SARA. In addition, corruption occurs frequently, and this is a consequence of the slow pace of enforcement and unassertive sanctions. (Terkper in Mann, 2004).

In Indonesia, some agencies/government organizations are independent entities so they can be used as a reference for the analysis of the DGT reforms such as the Corruption Eradication
Commission (Komisi Pemberantasan Korupsi/ KPK), Financial Services Authority (Otoritas Jasa Keuangan/OJK), Special Task Force for the Implementation of Upstream Oil and Gas (Satuan Kerja Khusus Pelaksana Kegiatan Usaha Hulu Minyak dan Gas Bumi/SKK Migas), Deposit Insurance Corporation (Lembaga Penjamin Simpanan/LPS) and Bank Indonesia (BI).

Accroding to Indonesian regulations, all agencies/entities have the authority to regulate human resources including recruitment, renumeration, promotion and dismissal of an employee at a certain level though to be appointed by the President with the approval of Parliament BIinstance, the Financial Services Authority and the Corruption Eradication Commission. Corruption Eradication Commission (KPK) employees are permanent employees and civil servants though the Commission was given special authority to set independently such as the eradication of corruption involving many elements such as the law and enforcement investigators and prosecutors from the police and the prosecutor can be appointed by the Commission. The recruitment process of the Corruption Eradication Commission's commissioners/staff is no longer based on political reasons as well as proximity to the country's leaders (free from the political elite). While the DGT as an institution specializing in tax under the Ministry of Finance does not have the authority to regulate human resources and is bound by civil service rules whereas the number of DGT employees comprise nearly $50 \%$ of the total employees of the Ministry of Finance and has a lot of challenges in the management of tax administration so that dynamic requires competent, professional and flexible human resources. The Head of DGT could be proposed by the Ministry of Finance by referring to the regulations of the State Personnel Board (Badan Kepegawaian Negara/BKN), and the Ministry of Administrative Reform.

The human resources in the Financial Services Authority and Corruption Eradication Commission consist of some elements, such as civil servants (Pegawai Negeri Sipil/PNS), police, attorneys (KPK). The Financial Services Authority consists of the Capital Market Super- 
visory Agency (Badan Pengawas Pasar Modal/ Bapepam), Bank Indonesia (BI), and the Ministry of Finance, so it has its own challenges in terms of acculturation, the cultural blending, or equalizing the different working cultures which takes some time. The DGT tends to have a relatively low risk since it consists only of one main element as in Bank Indonesia that only involves the personnel of Bank Indonesia which has been successful. The institutional transformation of the DGT has to get some support from other agencies such as the Corruption Eradication Commission especially in terms of the supervision and enforcement.

In terms of budgeting, an independent government institution (Ministry of Non-Government Institutions) is a structural organization under the president and is responsible to the president directly. The Corruption Eradication Commission and Bank Indonesia can determine their own budget including setting the operational costs, salaries, remuneration, and incentives, by referring to the standard costs assigned by the Ministry of Finance as a state financial regulatory agency and are obliged to submit a financial report to the Audit Board in order to maintain the accountability and transparency of the budget. Those institutions also have the authority to form their own units according to their needs since those independent institutions are formed based on specific and rigid duties and functions. The discretion regarding three of these powers is not owned by the DGT as a single directorate under the Ministry of Finance.

\section{INSTITUTIONAL TRANSFORMATION ANALYSIS OF THE DGT}

\section{Culture, Mindset, Image and Public Trust}

Public trust is an important issue to be considered in the institutional transformation of the DGT whose staff are often corrupt thus it tends to have a negative image in the eyes of society especially taxpayers. This should be changed by means of building good organizational culture and behavior at the DGT. According to its 2012 annual report, the cultural values of the DGT organization that have been built are: integrity, professionalism, synergy, services and perfection. It is these values that will support the achievement of the vision of the DGT to be a government institution that organizes a modern tax administration system which is effective, efficient, and trusted with such high integrity and professionalism.

The DGT, as the authority organizing the income of the state from tax collection, needs to be directed into being a profit center instead of a cost center. The Williamson Model mentions that the informal instutitution, custom, traditions and norms are important things that need to be reformed at the earlier stages of institutional reform, so the culture of the DGT needs to be led towards proactive, innovative, and aggressive action in all elements in the DGT both for the leaders and officials at central and local levels. The change in culture that is pro client becomes the new spirit for the business process of the DGT so it can optimize the state's tax revenue.

The honesty and trust values are important for the DGT in order to build up public trust. The public service announcements, slogans and campaign conducted by the DGT will not be effective if the behavior of the tax officers does not reflect the values of honesty and trustworthiness. Tax benefit utilization transparency is needed for the public so they will believe that the taxes they have paid are put to good use. The value of mutual respect positions the taxpayer as a partner instead of taxable object and maintains the equity and fairness. A change in the mindset of the tax officers towards the taxpayers could change the public/taxpayers' mindset regarding the DGT which has been marred by unscrupulous behavior by DGT staff, so the negative image of DGT, which has been one of debtcollector and corruptor could be converted into a more positive image. The mindsets of the tax officers and taxpayers, along with the strong leadership, are needed in the institutional transformation of the DGT.

\section{Institutional Arrangements for Tax Administration}

The DGT's bureaucratic reforms have been conducted since 2002 and are often referred to as 
the modernization of tax administration involving organizational reforms, information and technology-based business process development, and the implementation of good governance supported by human resource management which is based on the expertise, competencies and skills needed to optimize the state revenue. Some countries have also reformed their taxation system, for example in the European Community through the EC's fiscal blueprints to reform the state revenue agencies in organizational structure, human resource management along with the behavior, system and function of the tax administration agency, so that they can manage the tax in an effective and efficient way. This bureaucratic reform is aimed at assuring the state revenue agency has enough authority to design the organizational structure, set clear objectives, vision and mission, and has flexibility to carry out its duties and functions effectively and efficiently, supported by adequate resources and a strong legal framework in order to provide the high quality services and intensive supervision for the taxpayers.

According to the Williamson Model, DGT needs to get Environment Rights (institutional environment) including formal rules-of-thegame. Thus, institutional reform of the DGT needs to obtain the various external support from examples of good relationships with the Ministry of Finance, strong corporation with other public institutions in the executive, legislative and judicative, especially in sharing the data, investigation and enforcement. Beside these, the institutional reforms of the DGT need a strong and continuous commitment especially in terms of services and enforcement, so it is important that the application of better good governance is carried out.

The DGT does not have any authority in determining the internal structure design, budget allocation, hiring/firing of staff, and determining the salary rates since the DGT is under the Ministry of Finance along with other directorates general and the tax officers are subject to the regulations of the State Treasury Agency and Ministry of Administrative Reform (single direc- torate in Ministry of Finance model-SDMOF). In some countries, the state revenue is derived from duties and taxes which belong to one institution of state revenue (Austria, Netherlands, Greece, Columbia and South Africa). Meanwhile, in Indonesia, the tax is under the DGT and duties are authorized by Directorate General of Customs and Excise.

\section{Organizational Structure Reformation of DGT}

The organizational structure of the DGT is under the Ministry of Finance, so the internal design of its organization also follows the Ministry of Finance including the supporting functions such as budgeting, human resource management and information technology as with other directorates general under the Ministry of Finance. The DGT, as the implementation unit for fiscal policy in terms of Indonesian taxation, has conducted some transformation of organizational structure.

Bureaucratic reforms of the DGT, in terms of organizational restructuring, are aimed at overcoming the organizational issues at the operational level (vertical unit) such as the redundancy between control and inspection, the absence of a one-stop service, the structure that has not been fully supported in terms of good governance application, service standards that have not been maintained at a high level. Then there is a functional transition of fiscal policy from the DGT to the Fiscal Policy Office under the Ministry of Finance, so the tax target is determined by the Fiscal Policy Office as the administrator of state finance, while the DGT is a policy implementation unit in taxation.

Other public institutions, such as the Corruption Eradication Commission, support the institutional transformation of the DGT including the change of the organization's form by considering that the change should be accompanied by improved implementation of good corporate governance and the existence of checks and balances procedures to oversee the transformation process. 


\section{Human Resource Management and Tax Administration}

Human resources are one of the main keys to the success of tax administration, so strategy is needed to manage it. The DGT does not have the authority to manage human resources. Therefore, the DGT does not have formal strategic planning related to human resource management. Aspects of human resource management strategies include recruitment, enhancement of staff skills, leadership and talent management, staff satisfaction and achievement, diversity, demographic profiles of staff, remuneration and bonuses, setting the number of staff and job rotation. The DGT has an employee performance appraisal system, planned targets to increase staff capacity and to conduct training, and to provide rewards beyond those predetermined by the Ministry of Finance. However, DGT has no mechanism for periodical staff satisfaction surveys and should not do their own recruitment. Though, by its nature, it requires staff/employees who have competency/skills/specific expertise in the field of taxation that can not be obtained in a short time even through training.

DGT is also lack of flexibility in terms of remuneration and salaries as shall be subject to Apparatus State Civil Law, State Personnel Board regulation and Ministry of Administrative Reform since all of the employees belong to the civil servants (PNS). In 2011, the expenditures on wages/salaries of DGT employees compared to the total expenditure/expense for tax administration is relatively low (50.5\%) compared to other countries like Malaysia (82.4\%) and Singapore (55.3\%). Currently, in 2014 many echelon 3 in DGT that are not filled as a result of the long bureaucratic process to propose the echelon 3. Management of human resources to face the issue of incentives, remuneration and employee of living cost disparities of the DGT employees who work in locations with a high cost of living index tends todemotivate the workandbea disincentive for the DGT employees

\section{Monitoring and Law Enforcement on Taxes}

The DGT needs to listen to the expectations, desires, hopes, grievances, complaints of taxpayers. The United States, for example, established a tax ombudsman agency (the National Taxpayer Advocate Service-TAS), as did Canada (The Office of Taxpayer's OmbudsmanTO), to handle complaints, to guarantee the rights and obligations and to maintain a good relationships between the taxpayer and the tax authorities. The monitoring system is not only directed to the taxpayer but also monitoring to the quality of performance and integrity of the DGT personnel. In supervision and enforcement, taxpayers need to be viewed as a partner and receive treatment based on the principles of justice where there is no difference in treatment between taxpayers and there are no exceptions.

Indonesia established a special ombudsman institution in taxation field in order to in crease the tax payer compliance through Law on General Provisions and Tax Procedures is formed by the Supervisory Committee on Taxation (Regulation of Finance Minister No. 54/PMK.09/2008). Non-structural committee is tasked with and responsible to the Minister of Finance, supervise the implementation of DGT task includes observation, information gathering, and receipt of public complaints. To address the issue of public trust, equity and fairness for the taxpayer, image and branding of DGT's Officers, and DGT's accountability are necessary to strengthen the role of the Supervisory Committee on Taxation as an internal supervisor and ombudsman institutions through institutional strengthening supported by adequate regulation.

\section{Tax Compliance}

Tax compliance, in terms of time, starts from the enrollment in the tax system, the return of forms, tax calculation, tax reporting and payment of taxes.

The success of the self assessment tax system, such as the one in Indonesia, is largely determined by the taxpayer's voluntary compliance and supervision of the law enforcement apparatus of tax (enforcement) is indispensable. Tax compliance can be optimal if the magnitude and the mechanism of tax payment are not burdensome to the taxpayers, and the DGT may 
implement some solutions to these issues by reducing the tax rate and and subsequently it could be integrated with the multiple social data such as e-ID (Identity Card) and e-TIN (Taxpayer Identification Number). Moreover, taxpayers will dutifully pay taxes if there is the ease of paying taxes ranging from registration to the reporting so IT becomes extremely important, and filing tax return is not complicated.

\section{Coordination of Data Sharing With Public Institution}

The major issue currently at the DGT is the lack of coordination involving various public institutions such as in Ministry of Law and Human Rights and the Center for Financial Transaction Reports and Analysis. This coordination is important for the DGT to optimize state revenue and to prevent conflicts with other law enforcement agencies for example the National Police and the Attorney.

In fact, the coordination of the DGT with other public institutions has been arranged with Law 16/2009 on General Provisions and Tax Procedures. Coordination between the DGT as the tax authorities with other public institutions, including banks and Bank Indonesia, is provided for in Article 34.

Regulation of this data sharing coordination especially emphasized by Article 35A which states that every government institution, agency, association, and other party, is obliged to provide data and information related to taxation to the DGT which is regulated by Government Regulations. In order to conduct oversight, the implementation of the compliance with tax obligations as a consequence of the application of self-assessment system, the data and information related to taxation that come from government agencies, institutions, associations, and the other parties are required by the DGT. Strengthened by Government Regulation 31/2012 on Data Provision and Collection Related to Taxation, Article 2, government institutions, agencies, associations, and other parties are obliged to provide data and information to the DGT.
However, the current data access and minimal taxation information, for example the access to the data bank can only be made for a particular case in terms of criminal investigations in the taxation field and the tax collection framework. The issue of coordination with other public institutions is also a problem because of differences in job level, thereby to strengthen the institution by providing the level of tax positions with other strategic institutions that are indispensable. The DGT needs to use a multiple approach on law enforcement together with with other public agencies, especially the Police, Judiciary, INTRAC (PPATK), Corruption Eradication Commission (KPK) and related agencies under the coordination of law enforcement under the same roof to overcome the issues of coordination and data sharing.

\section{The Use of Electronic Services in Tax Administration}

Today, the use of IT for the user tax in Indonesia is limited only to the access to legal databases and the DGT web site. The results of the study conducted by the Corruption Eradication Commission showed that the DGT still needs to improve its tax database which is still not reliable. Until now, the database is not integrated and there is duplication of data. Therefore, the DGT will need to develop a specific roadmap to build a database that is fundamental to the potential exploration and oversight of taxpayer compliance.

Information technology is an essential element that must be corrected by the DGT. Business processes supported by optimal use of information technology are needed, especially in the process of profiling and taxpayer oversight. The issue of data access for tax and taxpayers strongly associated with the availability of resources and DGT competency, especially account representatives (AR) which exist in all regions in Indonesia. This issue is also related to the issue of flexibility in the management of human resources. 


\section{ALTERNATIVE TRANSFORMATION FRAMEWORKS OF DGT}

The institutional transformation of the tax administration are implemented gradually, while the stages in the transformation are described below:

\section{Phase 1: 100 Days to 6 Months}

Phase 1 is for the increasing and optimizing of the authority of the DGT, though it is still a single Directorate in the Ministry of Finance (MOF). The DGT will be given additional authority, flexibility in certain aspects in accordance with international best practice (nine authority-see Table 1), among others, personnel (human resource management, remuneration/ incentives for performance achievements), budget (the amount, allocation and reallocation of the budget) and determine the design of the internal structure with the approval and coordination of the Ministry of Finance. The authorization can be given through legislation, such as government regulations, or ministerial regulations. In order to guarantee the implementation of subsequent phases require the government's commitment which is expressed in laws or a roadmap document.

Strengthening of image, branding, public trust in the DGT as the tax authorities are accountable, transparent, clean and trustworthy. All these can be achieved by changing the mindset of the DGT officers and the public in their views of the tax. The DGT should be able to transform into a state institution that is more likely to profit centers and more looking at the taxpayer as a partner of the state in collecting tax revenue on the basis of equality and fairness. The DGT should be able to transform the whole mind set of employees from central to local tax officials to be more proactive, aggressive, innovtive, market driven and client-oriented.

In this stage, the DGT also needs to strengthen the infrastructure, including the use of ITbased data for secure tax revenue in 2015.

\section{Phase 2: Year 1 to Year 2}

Phase2 is where the DGT, with the addition of new authority but still under the Ministry of
Finance, optimizes and strengthens cooperation with taxpayers and another institutions such as INTRAC (PPATK), the Police, Judiciary, and the Corruption Eradication Commission (KPK). This includes carrying out various kinds of cooperation to learn and adopt from the success of tax authority institutions in other countries. In this stage, the DGT strengthens external factors and prepares, strengthens the support of both the environment of other public institutions such as INTRAC (PPATK), State Audit Agency (BPK), the Police, Judiciary, and the Corruption Eradication Commission (KPK), prosecutors, and even Parliament (executive, legislative and judicial). It is hoped that the lessons learned by the DGT can strengthen preparations to become a more independent institution.

\section{Phase 3: Year 2 to Year 5 (Mid Term)}

In this phase, the DGT is prepared to transform into a Unified Semi-Autonomous Body after all the components have been prepared for the process of transformation of the DGT as a regulatory, business process (good tax governance), organization (after a benchmarking study and collaboration with overseas and domestic institutions). Establishing this USB requires a legal basis to strengthen the position of the tax authority as an independent institution in accordance with laws or government regulations that regulate, among others, organization, business processes, authority, leadership, relationships between institutions, and transitional provisions.

\section{Phase 4: Year 5 and the Following Years (Long Term)}

In this phase, if necessary, the tax administration is managed with the involvement of various stakeholders including the private sector in the form of an oversight board and this can be done with a USB where conditions are optimal and mature.

\section{CONCLUSIONS AND RECOMMENDATIONS}

The performance of the DGT in terms of the resulting state revenues over the last ten years shows that it is still very buoyant, less elastic, 
with stagnant yields, and stable in terms of the increase of GDP. Now, the performance of DGT can be seen in the low of tax ratio, the low level of mandatory formal compliance, the low tax coverage ratio, and the low audit coverage ratio. The DGT faces institutional problems caused by overlapping and multiple interpretations related to the administration of the tax laws, tax law enforcement, data sharing and coordination between the DGT and other public institutions.

The DGT management performance is not optimal, effective or efficient, so what is needed is a road map of institutional change for the DGT. The international and domestic results of ascertaining best practices conclude that the DGT needs to change gradually, not with a 'big bang', and by providing the more flexible authority by remaining in the structure of Traditional Department or Single Directorate in the Ministry of Finance (SDMOF) which would lead to an organization structure which is semi-autonomous or a Unified Semi-autonomous Body (USB) that covers all the systems of taxation such as service, assurance, law enforcement and supporting roles.

The recommendations in the short-term focus on securing tax revenue in 2015 with the internal consolidation of the DGT to establish a good security team for revenue at the national level, regional level and the operational level, the consolidation of human resources, counseling extra effort and disbursement of tax receivables.

In order to broaden the tax base and capture the data about underreported tax, what is needed is external cooperation to optimize the implementation of Government Regulation No.31/ 2012 as the mandate of Section 35A of the KUP Act and activate the MOU with PPATK, Central Bank, OJK, and other technical ministries and internal cooperation in the Ministry of Finance.

In addition, it is necessary to establish a team to prepare the institutional reformation of the DGT under the Ministry of Finance to be a Unified State Revenue Agency and Semi-autonomous Body. The team will consist of teams for law and legislation, institutional teams (duties, the design of the internal structure, and SOP) and also operational support teams such as human resources, budget, infrastructure, and information technology. The Government through the Ministry of Finance is also expected to be active in supporting this process.

Legally, in order to realize the DGT's flexibility in managing human resources, it can be done in two ways, namely discretionary and attributive. In the short term, the government can draw up regulations that are discretionary, the President may delegate the development of human resources, including recruitment, appointment, rotation/transfer of employees to the DGT as the competent authority in accordance with Article 54 paragraph(1) of Law 5/2014. Then for the next step, compile attributive laws that give authority to the DGT to organize human resource management in coordination with State Personnel Board (Badan Kepegawaian Negara/ BKN), and the Ministry of Administrative Reform.

The problem of the limited authority of the DGT in terms of the budget can be overcome by providing the DGT with the flexibility to have a separate budget with and work plan from the budget of the Ministry of Finance. Under Government Regulation 90/2010, Article 1 paragraph 2, the term "other agency budget users" is stated and then the new DGT will be a budget user as stipulated in Law 17/2003 which is not combined with the budget of the Ministry of Finance, but the unit will remain under the coordination of the Ministry of Finance in terms of fiscal management in accordance with Law 17/2003 Article 6 paragraph (2) letter a.

The DGT needs to be evaluated continuously to support changes in the structure and institutional authority over the alignment of vision, mission, strategies, expected outcomes, missiondriven work and inovation, impact and engagement to make continuous improvement reviews (CIR) each month.

In the subsequent annual programme, the priority is to improve the public trust through good governance. This needs to be done through the development of organizational culture and behavior of all the componets of the DGT based on the values of integrity, professionalism, 
synergy, service and excellence, as well as the implementation of the code of ethics. In addition, the leadership selection process of the DGT needs to be done openly and using a merit-based system like the KPK leadership selection process, the placement of the Commission officials, BPK and PPATK, as well as the transparency of disclosure of assets and wealth of public officials in the DGT through LHKPN delivery to the public.

The DGT needs to optimize the program of good governance through examination-based risk analysis and coordination with the relevant third parties sharing the data, investigation and collection of taxes as mandated by the KUP Act in optimizing revenues such as cooperation with PPATK, BPK, the Police, and KPK.

It is necessary to formulate a special regulation on coordination in the field of tax enforcement to strengthen enforcement and improve taxpayer compliance. The process of institutional change of DGT from the traditional department towards a Unified Semi-autonomous Body as a separate agency with the Ministry of Finance requires a commitment by the government, such as happened in Japan, Mongolia and Vietnam. This commitment is needed to ensure that the stages of institutional change can be realized and improve the performance of taxation in Indonesia.

\section{REFERENCE}

Acharya, Shankar. 2005. Thirty Years of Tax Reform in India. Economic and Political Weekly, Vol. 40, No. 20 (May 14-20, 2005), pp. 2061+2063-2070

Carling, Robert. 2009. Ten Principles for Tax Reform. Policy; Spring 2009, Vol. 25 Issue 3, p9

Crandall, William \& Kidd Maureen. 2006. Revenue Authorities: Issues and Problems in Evaluating Their Success. IMF Working Paper/06/240

Crandall, William. 2010. Revenue Administration: Autonomy in Tax Administration and the Revenue Authority Model. Technical Notes and Manuals: IMF
Delay, Devas, and Hubbard. 1998. The Reform of Revenue Administration: A Study for The Department for International Development (DFID). The School of Public Policy University of Birmingham. p.39

Duncan Bentley. 1998. Taxpayer's Rights: An Internation a Perspective. The Revenue Law p. 28

Haldenwang, Christian Von., et.al. 2013. Tax collection in developing countries - New evidence on semi-autonomous revenue agencies (SARAs). German Development Institute/Deutsches Institut für Entwicklungspolitik (DIE) and Deutsches Evaluierungsinstitut der Entwicklungszusammenarbeit (DEval)

Hogye, Mihaly. 1998. Tax Policy and Tax Administration in International Comparison. Society and Economy in Central and Eastern Europe, Vol. 20, No. 2, The End of a Millennium: The Dynamics of External and Internal Politics in Central and Eastern Europe: Part II (1998), pp. 235-247

Manasan, Rosario G. 2003. Tax Administration Reform: Semi-Autonomous Revenue Authority, Anyone?. Philippine Journal of Development Number 56, Second Semester 2003, Volume XXX, No.2

Mann, Arthur J., 2004. Are Semi-Autonomous Revenue Authorities The Answer to Tax Adminsitration Problems in Developing Countries?-A Practical Guide. Fiscal Reform in Support of Trade Liberalization: Washington DC 20005

Mansfield, Charles Y. 1988. Tax Administration in Developing Countries: An Economic Perspective. Staff Papers - International Monetary Fund, Vol. 35, No. 1 (Mar., 1988), pp. 181-197

OECD. 2013. Tax Administration 2013 Comparative Information on OECD and Other Advanced and Emerging Economies. OECD

Phillips, Max Everest. 2010. State-Building Taxation for Developing Countries: Prin- 
ciples for Reform. Development Policy Review, 2010, 28 (1): 75-96

Taliercio, Robert. 2004. Designing Performance: The Semi-Autonomous Revenue Authority Model in Africa and Latin America. World Bank Policy Research Working Paper 3423, October 2004
Vehorn, Charles L. 2011.Fiscal Adjustment in Developing Countries through Tax Adminstration Reform. The Journal of Developing Areas Volume 45, Single Issue, Fall 2011 pp. 323-338. 